\title{
5 \\ The last of the ancients the first of the moderns?
}

Do I contradict myself?

Very well then I contradict myself

(I am large, I contain multitudes)

(Walt Whitman, Song of Myself, 11. 1325-7)

In one of his fragments Rousseau spoke of a man who 'was one of the moderns [but] who had an ancient soul' (III: 643). This could have been an epitaph for his many autobiographical statements. Rousseau was a weak and often insecure individual but he was also a man with an astonishing confidence in his literary abilities. As early as in the Discourse sur les sciences et les arts he predicted that his essay 'would live beyond its century' (III: 3). And so it did. Approaching the tercentenary of his birth, the Swiss note-copier's works are on the reading lists in sundry faculties all across the academic horizon - from anthropology through music and philosophy to political science and even botany.

Why this continued interest in a man who was 'from childhood to his death but an artisan, a bureaucrat or minor employee just as much as a writer' (Launay 1963: 22)? This question is as easy to ask as it is difficult to answer. A short, adequate - but ultimately unsatisfactory - answer is that he was a genius - though not always a very attractive one. In Dictionaire de la Musique, one of his lesser known works, he described a genius almost poetically as:

He who makes the silence speak, who restates thoughts through emotions, and emotions through subtle allusions, who wakes passions in the depth of the heart ... [He who], even when depicting the horrors of death, instils into the heart a feeling of life, which never deserts him. (V: 915)

In his more sublime moments, Rousseau did exactly this. Uniquely for a political thinker, he combined a sharp analytical mind with the poetic 
sensibility of the composer and the novelist. Rousseau, unlike postmodernists, did not renounce reason but he ceaselessly insisted that the passions ought to be granted their rightful place in the political pantheon. Rousseau, like Plato, recognised that it is multiplicity of the soul and the self which, perhaps more than anything else, characterise l'homme civil. His whole philosophical endeavour seems like one long paraphrasing of American poet Walt Whitman's dictum 'I am large. I contain multitudes'. Rousseau insisted that man was large enough to contain paradoxical traits that could not be reconciled. His project was to seek a formula for how the different natures could be made to co-exist without mental torment and social anomie.

Being victims of a culture that values specialisation, it is difficult for us to grasp the scale of Rousseau's ambition. Specialists by definition focus narrowly. Modern political theorists have had the rather unfortunate, if understandable, habit of focusing on Rousseau's so-called 'political writings' to the exclusion of his other writings. We cannot, however, fully comprehend his political philosophy until we have grasped its relation to his so-called non-political writings. An understanding of Rousseau requires us to understand, as Geraint Perry puts it, how he sought to find a mechanism for teaching individuals to 'be men, women and citizens' (Perry 2001: 247). More specifically, how to 'create a virtuous circle in which transformed human beings could live in a transformed society in which all could equally enjoy a sense both of self-fulfilment and community with others' (248). The activity of being a citizen is intertwined with that of being a whole individual, an individual who could see the beauty in nature, enjoy music, and at the same time perform the duties of a virtuous citizen. This, of course, was not a unique ambition for a great philosopher. Plato, Kant, Hegel and even Mill (to name but a few) aspired to do the same.

Did Rousseau succeed in his endeavour? He recognised - like Burke that the advent of Godless materialism was undermining the moeurs, and that patriotism and nationalism were necessary and, indeed, commendable doctrines, which could reverse the trend caused by the progressing disenchantment of the world. Yet Rousseau - perhaps unlike so-called contemporary conservatives - was not content with the existing inequalities. He was appalled by the treatment of the poor and the snobbishness and wantonness of the rich. This might make him a hero for the political Left. Yet his political remedy was anything but Jacobin. The cure he proscribed was not redistributive programmes, still less schemes for penalising the rich. Rather his solution was to recapture the lost innocence of mankind through negative education (with the occasional 
institutional incentive thrown in alongside the pedagogic efforts). Political institutions were necessary, as discussed earlier in this work. Yet, Rousseau never succumbed to the illusion that perfect constitutional arrangements could lead to a perfect society. Nor, indeed, would society be much improved if even the wisest men were to be given the reigns of power. Leadership was but a part of the equation. A good polity required both wise rulers and enlightened and virtuous citizens. That is to say, a recognition that there could be no rights without duties, no entitlements without obligations. This realisation was not lost on great men. As Susan Dunn has observed: 'When John F. Kennedy electrified a generation by declaring in his inaugural address in 1961, 'Ask not what your country can do for you, ask what you can do for your country' - Rousseau was speaking to us again - with a Boston accent' (Dunn 2002: 29).

Rousseau - exactly like John F. Kennedy - understood that sacrifice is a necessary part of a working polity. He was never an institutionalist (like Madison or Mill), though he greatly admired Montesquieu. He approvingly cited the latter's observation - from Considérations sur les causes de la grandeur des Romains et leur décadance - that 'at the birth of societies it is the legislators who shape the institutions, after that it is the institutions who shape the legislators' (III: 381). (Although he also stressed that institutions were not the only factors to shape the law-makers' actions.) Rousseau also shared - indeed advocated - the view that the rulers should be subjected to checks and balances. Why did believe this? Possibly because he, as a commoner, had been at the receiving end of the tyranny of the property-owning aristocracy. As he wrote to the French king's censor, de Melherbes, in a letter from 28 January 1762: 'I dislike those who rule others, I hate the great class, their coldness, their prejudices, their petty sentiments, and their excesses, and I would hate them even more if I despised them less' (Rousseau in Hendel 1937: 219).

It was, perhaps, for this reason that he offered his own (democratic) unique solution to the age-old problem of quis custodiet ipsos custodes who guards the guardians. He did this by suggesting how referendums could be a democratic check on the encroachment of power by the magistrates and developed a case for a constitutionalism, which was both conservative and democratic.

The belief in democracy - in mass man's ability to take responsibility for his own life and his society - was an especially new departure. Voltaire, by contrast, believed that there were 'very few republics on Earth [because] [m] en rarely deserve to govern themselves (Voltaire 1962: 257). ${ }^{1}$ Where Locke, Madison and Montesquieu envisaged that the lawgivers should be 
held in check by second chambers, courts or a federal division of powers (i.e. through non-democratic and elitist schemes), Rousseau (inspired by the political system of his native Geneva) championed the people as the check on the rulers.

Beginning in the Discourse sur l'inégalité and the Discourse on Political Economy, and continuing in Du Contrat Social and Lettres, Rousseau pointed to the veto-power of the ordinary citizens as a bulwark against radical changes enacted or proposed by over-eager lawmakers. Recognising that the veto-power of the people - such as it existed in Rome - at all times have been viewed with 'alarm by the leaders' ('ont été de tous temps l'horreur des chefs') (III: 428), Rousseau believed that the rulers' opposition to the veto-power of the people was the best proof of the efficiency of this system as a constitutional safeguard (428). Far from advocating direct legislation, Rousseau stressed the necessity of establishing a check on the representatives. He advocated a system 'in which individuals [were] content with sanctioning the laws' (III: 113) - but do not make the laws themselves. These views make it difficult to maintain Riker's view that Rousseau believed 'that by reason of popular participation democratic government embod[ies] the will of the people and cannot therefore oppress' (Riker 1982: 9). Quite the contrary. Rousseau would have had some sympathy for Riker's view - though we would have been alarmed by his rationalism and absurd insistence that politics might be reduced to mathematics and algebra.

Rousseau's trust in natural conservatism provided him with the institutional means of avoiding radical and revolutionary change - something which he (like Burke) detested. He developed these views into a constitutionalist doctrine of gradual reform and piecemeal change, the principles of which were outlined in Du Contrat Social, the Discourse sur l'inégalité, and given a concrete form in Lettres écrites de la montagne. The latter is often - though unfairly - overlooked. For while the latter work is rather lesser known than his more abstract treatises it is worth noting that Lettres was deliberately written to demystify his theories. Rather than being a merely apologetic tract, Lettres was also a popularised version of thoughts which he had previously expressed in a theoretical language. One could perhaps say that Lettres stands in the same relationship to Du Contrat Social as Kant's Prolegomena stands to his Critique of Pure Reason. In Lettres Rousseau proceeded through examples rather than through stringent deductive reasoning. The result was a thorough defence of the principles of democratic constitutionalism. In Lettres he advocated the principle of checks and balances and expressed unequivocal support of at least one 
aspect of British constitutionalism, a system which 'offer[ed] a model of a just balance between restrictive powers' (III: 874). Like Montesquieu (whom he revered), ${ }^{2}$ Rousseau saw England as a model. He was not (as Burke erroneously believed) an opponent of the British system of government.

Rousseau was aware that his writings could be misinterpreted - there is a high price to be paid for eloquence. Defending himself against the charge raised by Louis-François Trochin, the chief prosecutor of Geneva, he reiterated his support for a balanced constitution. In Lettres écrites dans la campagne, Trochin had asked the rhetorical question; 'what point is there to having a government under which the people has an unlimited right to legislate'. Rousseau's answer was simply 'I agree' (III: 875). That is, he agreed that the people's power to legislate directly had to be restricted. But Rousseau - perhaps unwisely given the circumstances - did not restrict himself to agreeing with the prosecutor. Being a thinker he developed a philosophical response to a legal charge. Rousseau showed that the Genevan constitution was not consistent with the principle of a balanced government, and hence incompatible with his doctrine as laid out in $D u$ Contrat Social. The Petit Conseil - the ruling body in the city - was unrestricted in its powers. While opposed to direct and unrestricted democracy (an opposition most clearly stated in the Dedicace in the Discourse sur l'inégalité), he was equally adamant that unrestricted rule by the elite was unacceptable. Hence, while the British constitution is not at all perfect, it was preferable to the prevailing system in Geneva, as the British constitution was a balanced one - while the Genevan constitution was not (III: 875). At least not in practice, as he had previously thought (III: 809). This philosophical analysis was lost on the prosecutor, whonot surprisingly - did not respond in kind. Rousseau's books were symbolically burned in the aftermath of his unsuccessful intervention. This is not the important matter here. What is interesting, from a philosophical point of view, is the thrust of Rousseau's response. As a true philosopher of freedom - albeit of a non-liberal sort - Rousseau praised the English system under which 'no citizen is imprisoned in contravention of the law, his home is sacred' (III: 875). Again this doctrine would have been unoriginal had it not been for Rousseau's (in the true meaning of the word) 'populism'.

In advocating the referendum as an alternative constitutional safeguard he sided with the people - not with the rulers. This is not surprising. Rousseau's position vis-à-vis other philosophers was always that of an outsider, and of a spokesperson of the speechless and underprivileged. 
Constitutionalism was never an end in itself for Rousseau. Social justice was the main cause of his indignation. As he wrote in one of his unpublished Observations, 'the main source of all evil is inequality' (III: 50). While statistical evidence from the period must be treated with utmost caution there are indications that there was considerable - and increasing - inequality at the time. Less than 2 per cent of the population held onethird of the land. While representing only 5 per cent of the population, the landowners received 50 per cent of the landed capital and almost the totality of the rents from farms, sharecropping, various local taxes and rights of domain of all kinds. ${ }^{3}$

Most other constitutionalists were well-to-do aristocrats (Montesquieu), wealthy bourgeois businessmen and lawyers (Madison), professors (Kant and Hegel) or on the pay-roll of the rich and influential (Locke). Rousseau, the watchmaker's uneducated son, was not. And it showed. His constitutionalism was not driven by a fear of the masses but rather by a distrust of the rich as a class - and a rare trust in the people. He was interested in constitutionalism precisely because he realised that checks and balances were needed to protect the masses against the rich - and because he realised that the existing system did not protect the impoverished masses. In the cause of history, wrote Rousseau, 'legal power turned into arbitrary power' (III: 187). While political societies were founded upon a common interest, these commonwealths degenerated as the rich exploited the poor; 'the same vices that [rendered] social institutions necessary, [were] the same which rendered the abuse of these institutions unavoidable' (III: 187). In the absence of checks on the rulers 'political distinctions would necessarily lead to social distinctions [and hence] the inequality between the people and their chiefs' (III: 188). ${ }^{4}$ Or as he put it in Du Contrat Social:

Under a bad government ... equality is only an appearance and an illusion; it serves only to keep the poor in their wretchedness and sustain the rich in their usurpation. In truth, laws are always useful to those with possessions and harmful to those who have nothing; from which it follows that the social state is advantageous to men only when all possess something and none has too much. (III: 367)

'Everything', wrote Rousseau scholar Jean Starobinsky, 'begins with the experience of social outrage' (Starobinsky 1988: 221). For Rousseau tout le mal vient de l'inégalite - inequality is the root of all evil. Rousseau occasionally found it difficult to contain his anger. In a letter to a Mme de Francueil he angrily asserted that 'it is the class of the rich, your class, that 
steals the bread from my children' (II: 143). Such statements, not surprisingly, have been used by generations of radicals and other proclaimed champions of the downtrodden. And yet Rousseau - as we have noted - did not quite fit the revolutionary bill. While an uncompromising foe of an economic system that sacrificed people for profits, he did not advocate the abolition of private property, still less did he seek to return man to a bygone age of pre-modernism. His economic philosophy - like that of Adam Smith - combined the doctrines of the physiocrates and the mercantilists. Yet, where the Scot combined the physiocrats' zeal for free trade with the mercantilists' aversion against agriculture, Rousseau did the opposite, placing agriculture at the centre of his economic theory - and rejecting the reliance on free trade. His rejection of laissez-faire was not, however, merely based on economic considerations. Although more of an economist than often recognised (Fridén 1996), his conclusions stemmed more from ethical beliefs than from considerations concerning profitability. He sought to establish an ethical economic system.

Arthur Schoppenhauer once described Rousseau as 'undoubtedly the greatest moralist of all times' (Schoppenhauer cited in Dent 1991: i). Not entirely accurate if one judges him solely on the less than flattering autoportrait in Les Confessions, but a philosophically accurate assessment given the thrust of Rousseau's endeavour to challenge modernity and its debauchery of morals. One might (with Alistair MacIntyre) conclude that the moral philosophy of modernity is a catalogue of theories seeking to justify good actions without recognising that goodness exists - clearly an impossibility. The philosophers of modernity have (in vain) sought to develop a theory of the concern for the welfare of others that took selfinterest as the unquestionable point of departure. And while Kant deserves credit for showing that any idea of goodness required the gute Wille (the good will) as a necessary condition (an action is 'good' only when the individual's intentions are good), Rousseau deserves credit for putting Kant on to his attack on utilitarianism. Kant's categorical imperative would not have been possible without Rousseau. 'For an action to be just', wrote Rousseau, 'it must be so in all its relations.' Eric Weil might have been exaggerating when went as far as saying that it took a Kant to think Rousseau's thoughts' (Weil 1952: 3). Yet he arguably had a point. The German's philosophy would have been unthinkable had it not been for Rousseau (Velkley 2002: 18).

While Mandeville, Hobbes, Madison and even - in our day - John Rawls appealed to rational egoism in order to establish a system of common welfare and goodness, Rousseau despised this view. He spoke scornfully 
of those who 'get an odious pleasure out of seeking for sinister interpretations of everything and of seeing nothing from the good side, not even what is good' (Rousseau 1979: 237), and the Savoyard Vicar attacked what he called a an 'abominable ... philosophy[,] one which is embarrassed by virtuous actions, which [must] fabricat [e] base intentions and motives without virtue' (Rousseau 1979: 283).

He not only rejected that the result of their endeavours could be described as 'good', he also - and more importantly - challenged the description of man as an individual seeking his hedonistic and rational self-interest. The Hobbesian caricature of man was not only morally repugnant, it was also inaccurate. The rational choice theorists from Hobbes onwards have contended that we help the poor for fear that we might find ourselves at the bottom of the social order (Rawls 1971: 79). Rousseau did not reject that individuals sought self-protection (amour de soi-même), yet this was not the only impulse that drove them. 'We must not', he wrote in a passage in Discourse sur l'inégalité,

confuse selfishness [amour propre] with self-love [amour de soi-même]; they are two very distinct passions both in their nature and in their effects. Selflove is a natural sentiment, which inclines every animal to look after its selfpreservation, and, which guided in man by reason and qualified by compassion is productive of humanity and virtue. Selfishness is but a relative and factitious sentiment engendered in society, which inclines every individual to set a greater value upon himself than upon any other man, which inspires men with all the mischief they can do to one another. (III: 219 , italics added)

Rousseau's doctrine thus differed radically from the utilitarian and Hobbesian theories, which elevated hedonism, and made a virtue out of vice. While recognising that man sought self-preservation (amour de soimême), Rousseau emphasised that this was 'qualified by compassion' with our fellow men - and that this feeling of pitié was completely unrelated to our narrow self-interests. Yet as the proto-Kantian thinker he also was, Rousseau was not content with simply drawing attention to the existence of compassion as a strong motive driving men's actions. He was eager to establish what we (for want of a better expression) might call 'transcendental' conditions for our natural urge to do good. In a famous passage he wrote:

Although compassion [pitié] is native to the human heart, it would remain eternally quiescent unless it were activated by imagination. How are we moved by compassion? By getting outside ourselves and identifying with 
the being that is suffering. We only suffer as much as we can believe him to suffer. It is not in ourselves but in him that we suffer. (V: 395)

Compassion thus became empathy; the ability to step into someone else's shoes and then step out again. Our fellow beings' sufferings warm us and give us a common sense of humanity. But how are we to imagine what it is like to suffer? Are we still capable of feeling compassion in an age and at a time when amour propre has the upper hand? Rousseau's answer was negative - but not entirely disparaging. Society - in its bourgeois variant - was an obstacle to our natural goodness. As he wrote in the fragment Le Bonheur Public: 'What makes human misery is the contradiction, which exists between our situation and our desires, between our duties and our inclinations, between nature and social institutions, between man and citizen' (III: 510).

Our true self had to be re-awakened (a project he undertook in Emile). Through 'negative education' man would, or could, rid himself of the artificial mask of vanity and that unnatural selfishness which had become the hallmark of the society Rousseau despised. Rousseau left no one in doubt that a just and moral society could not be re-established except through a concerted effort. Education - public as well as private - was necessary. The bon sauvage was no longer. In our age 'we have to develop our social feeling as we become enlightened' (V: 395). Our compassion for other beings thus required education and a 'great deal of acquired knowledge' (V: 395). Not academic knowledge, but knowledge gained through practical experiences and an apprenticeship in the art of life.

Rousseau's educational ideal, therefore, was not totalitarian. ${ }^{6}$ Not grounded in a desire to shape man in his own image. Rather, 'negative education' was aimed at rediscovering the individual's natural - but hidden - self. In a sense Rousseau's plan for negative education sought to offer mankind a new beginning. This was necessary as a return to the original state was an impossibility.

Man - as he lived before he was lured into civilisation - was a loner who did not engage in lasting relationships:

Such was the condition of infant man; such was the life of an animal confined at first to pure sensations, and so far from harbouring any thoughts of forcing her gift from nature, that he scarcely availed himself of those which she offered to him of her own account. (III: 178)

But difficulties soon arose, and 'original man' (Rousseau did not mention women $)^{7}$ gradually became engaged with other men, learned to co-operate - and showed compassion for fellow members of his species. Gradually 
the blissful life in the state of nature that preceded civilisation was somehow broken up and distorted when the rich - through the power of their wealth - usurped power, and relegated their fellow-men to an enslaved existence.

Such was, or must have been, the origin of society and law, which gave new fetters to the weak and new powers to the rich, irretrievably destroyed natural liberty, fixed forever the laws of property and inequality; changed an artful usurpation into an irrevocable right; and for the benefit of a few ambitious individuals subjected the rest of mankind to perpetual labour, servitude and misery. (III: 178)

The losers were conned into accepting their miserable lot through deception. They lost not only their freedom, but also their sense of direction. Marx, who saw this as clearly as Rousseau (Marx 1977: 121), called it 'alienation' ('Entfremdung'). Rousseau too found that man had become an alien; a vain being on a meaningless - and unnatural - quest for amour propre. Of course history was not linear. There had been moments when man had - for a short period of time - managed to overcome the predicament of a depraved civilisation, as was the case in the Roman republic, just as there were lacunae of the good (natural) life in the serene alpine villages described in La Nouvelle Heloïse. But these were exceptions. As a rough rule civilisation had depraved man, yet - as these examples showed - there was a way out of the misery if man could be taught to live together under a just constitution. Was Rousseau right to think so? Had he found the right cure?

Perhaps both. Perhaps neither. Like Plato, Rousseau later changed his prescribed cure as well as making changes (or at least very significant additions) to this system. The political and educational blueprints (Emile and $D u$ Contrat Social) were far from identical with his more practical suggestions in Projet $d u$ Corse and Considérations sur la gouvernement $d u$ Pologne. Whereas in Emile he had been concerned with the private sphere - with private education - the focus in Projet sur la constitution de la Corse and Considérations sur la gouvernement $d u$ Pologne changed to public education. Likewise the rather more institutionalist account in $\mathrm{Du}$ Contrat Social and Lettres gave way to a more nationalist account in the later writings. The common denominator in the latter works was that the establishment of public mores were essential for maintaining a healthy society. This view was one that Rousseau always had held - as one can see from both the Discourse sur l'inégalité and Political Economy - but in the later writings it took centre stage. 
Social injustice, amour propre, and the disenchantment of the world; these were the problems that prompted Rousseau to become a writer. The problem for Rousseau was that he - when he came to write his later writings (Projet sur la constitution de la Corse, Considérations sur la gouvernement $d u$ Pologne and possibly his writings on international relations) - realised that the situation was worse than he had hitherto expected, and that he had overlooked other causes which further weakened the society of men.

Rousseau lived at a time of rapid social and economic change. The only constant in modernity is change, but not all thinkers have realised this. Rousseau, like Marx and Hegel, was a thinker who was aware that he was living in the world of radical transformation. World history is dynamic, yet can only be described in static terms. Rousseau, the last of the ancients and the first of the moderns, lived on the threshold of the modern age. His upbringing took place in a static society in a city shaped by the classical republican virtues, and it was these ideals of the small, self-sufficient, societies he initially held up as a model in his political writings. Yet the reality that he increasingly faced was that his model was being made obsolete by large territorial states and an economic system that suited these. Previously Rousseau had noted that amour propre and declining patriotism posed a problem even in the model cities. Now he was faced with the problem that the preferred model was vanishing - and with it all the virtues that were to hold society together.

Not all prominent thinkers have taken the consequences of radical change into account. Aristotle - the undisputed chronicler of the ancient city states - chose to ignore the changes that were taking place under his philosophical nose; i.e. his pupil Alexander the Great's conquest of the world and establishment of a world empire that made the city state all but a meaningless concept, and proved that Aristotle's science of politics was past its sell-by date perhaps even before the polymath had penned it. Other thinkers have reacted to momentous changes by making change the central element of their thinking (e.g. Hegel, and perhaps even Plato), still others - and this is where we find Rousseau - have sought to update their philosophies and take account of the momentous changes. In Rousseau's case this updating led - albeit unintentionally - to the establishment of the most successful of all the ideologies of modernity: nationalism.

Poor Jean-Jacques, so often cited, so rarely quoted, so consistently misunderstood. 'C'est la faute à Rousseau' ('It is Rousseau's fault') said one of the characters in Hugo's Les Misérables (Hugo 2000: 313). A bit of an exaggeration - but not widely off the mark. History's verdict has been harsh. Hippolyte Taine and other historians of the French Revolution have 
wasted few opportunities to denounce his views. Rousseau is the strawman par excellence, the quintessential scapegoat, a literary hate figure who could always be invoked when a critic was in need of a culprit for the miseries of modern society. And this is not only true for historians of the French Revolution. Conor Cruise O'Brien's assessment of the philosopher is as revealing as it is typical (and ill-informed):

Rousseau's place in France now appears perennially secure. He simply comes with the language. But Rousseau also holds an influential place within the English speaking world through the vogue for the 'politically correct' and 'multiculturalism' now dominant in certain faculties of several major American universities ... The malignant magic of the grand charlatan is liable to be with us for some time. (O'Brien 2002: 315)

Rarely has an erudite man been more misinformed. Rousseau was many things; a vagabond, a note-copier, a poet, a composer, a pedagogue and a political scientist but he was never a multiculturalist, and he certainly did not go along with the liberal secularism of the so-called politically correct. Of course many 'progressives' have misinterpreted Rousseau (see Gourevitch 1999 for an overview). Yet these advocates of the Jacobin interpretation have tended to overlook his later writings, moreover they have ignored Rousseau's ceaseless profession of his Christian faith, his opposition to modernity and his support for private property. Indeed, one wonders which of the great man's works they have read to find support for their claims.

Rousseau was a compassionate conservative - and he did not believe that his doctrine was compatible with multiculturalism. His chief political concern was compassion with the poor -but it was (in his view) impossible to create the political and moral conditions for helping the poor without the establishment of a nation state, that is to say without the establishment of a sense of common solidarity between citizens.

This was a new departure. Communitarian thinkers like Cicero and Machiavelli had earlier emphasised the necessity of the virtue of patriotism, the love of the fatherland and the willingness - if need be - to sacrifice oneself for the commonwealth. Rousseau both shared and went beyond the aspiration of the ancient masters. As a patriot this citoyen de Géneve never tired of showing how our emotional affection for the fatherland could produce the most illustrious acts of bravery and self-sacrifice. In $D e$ la Patrie, an early fragment, he had pondered 'why it is that the Earth, the common mother of all people, does not create the same sentiment as that of the fatherland' (III: 534). However, this patriotism was with the small 
community in which everyone knew everybody. The patriots of ancient Sparta sacrificed themselves for people they knew and loved, and whose fate concerned them personally. With the growth of the territorial state (after the Treaty of Westphalia in 1648), sacrifice for the small community was politically meaningless as the small communities had become politically unimportant, and historically obsolete. Nationalism, Rousseau was to suggest, proved to be the solution. Whereas patriotism, as used by Machiavelli and Cicero, was identification with a concrete community, the nationalism proposed by Rousseau was identification with, what Benedict Anderson has aptly described, 'an imagined community'. In Anderson's words, in a nation the political community is 'imagined because the members of even the smallest nation will never know most of their fellow members, meet them, or ever know of them, yet in the mind of each lives the community' (Anderson 1981: 6). Rousseau saw this - and acted upon his newly discovered insight. Yet this is not commonly recognised in the historical overviews of Western political philosophy nor is it commonly recognised among scholars of nationalism.

Rousseau's place in the intellectual history of nationalism is too rarely acknowledged (Velkley 2002: 32). This is regrettable. The fact is that healongside Herder and Fichte - developed a model for: 1) how the emotional attachment to a nation could be generated; 2) how a redevelopment of the ancient doctrine of patriotism could be transformed into a new, powerful doctrine; 3 ) how this could be done in practice; and 4) how a doctrine of nationalism could perform the functions of civic religion in ancient Greece and Rome.

Rousseau, as already noted, was not the only thinker to develop a case for nationalism. Herder and Fichte are commonly recognised as the founding fathers of this not unproblematic doctrine. Yet the two Germans, unlike Rousseau, were not sociologists. While seeking the same as Rousseau (i.e. social cohesion and solidarity), their case for nationalist sentiments was always clothed in mysterious and metaphysical notions of the Volksseele - literally the common soul of the people (an entity that Fichte claimed always had existed). In theoretical speak, the Germans were pre-mordialists. Rousseau, by contrast, was a constructivist (though a conservative and communitarian one at that). While he recognised that a people might share a common history and ancient myths, he regarded the nation state as an artefact. And it was in order to make this artefact into a vehicle for social cohesion that he suggested how a sense of patriotism could be developed.

It is easy to reject this philosophy as dated or altmödisch. Yet it is political correctness notwithstanding-difficult to claim that states without 
a common sense of direction and a common set of values have thrived even in the age of multiculturalism. Maybe Rousseau had a point after all. And maybe his true allies are those on the political Right who question the wisdom of secular multiculturalism.

\section{Last thoughts}

'A true lawgiver must have a heart full of sensibility. He must fear himself and love mankind.' Edmund Burke penned these words in his Reflections on the Revolution in France (Burke 1986: 281). It is indicative of the misperception of Rousseau's philosophical project that these words just as easily could have been written by the very man whom Burke erroneously - held responsible for all evil emanating from the French Revolution. Recapturing the lost innocence, or rather salvaging whatever was left of it, was Rousseau's aim - just as it was Burke's.

But of course there were differences. Rather than stressing the importance of institutions, Rousseau pointed to 'negative education' as a mechanism, which could and would prevent ingenious schemes of elitist legislation based on rationalistic hubris and misplaced delusions of scientific omnipotence.

As befits a classical thinker, Rousseau's contribution to Western philosophy was rich in detail and even broader in scope. Like other critics of modernity - Kierkegaard and Pascal come to mind - Rousseau's philosophy was a showdown with a society marred by Godless materialism, absurd social inequalities, and unnatural inter-human relations. Men, argued Rousseau, would not be set free if left to himself. Liberty, as understood by Rousseau, could only be acquired once man - and Rousseau was not gender-neutral - had reconciled his natural, spiritual, and social sides of himself with the requirements of living in an advanced civilisation. Men, argued this most unlikely of thinkers, could only be free when - or if - they recognised the imperatives of living in a family, in a republic and in harmony with a universe created by God: Vitam impendere vero!

\section{Notes}

1 It should perhaps be noted that Helvétius expressed some sympathy for democracy (not surprising given his views on equality). See Irwing Louis Horowitz, Claude Helvétius: Philosopher of Democracy and Enlightenment (New York: Paine-Whitman Publishers, 1954).

2 This reverence is perhaps best illustrated by a letter he wrote to Jean Perdriau 
when Montesquieu died: 'You will regret as I do the death of the illustrious Montesquieu. He had no need of so long a life to become immortal; but he ought to have lived for ever to teach people their rights and duties' (III: 277).

3 See Fernand Braudel and Ernest Labrousse (eds), Histoire Economique et Sociale de la France (Paris: Presses Universitaires de France, 1970), pp. 139, 476-7.

4 Compare this statement with Burke's observation in A Vindication of Natural Society: 'It was observed that men had ungovernable passions, which made it necessary to guard against the violence they might offer to each other. But a worse and more perplexing difficulty arises, how to be defended against the governors? Quis custodiet ipsos custodes?' Edmund Burke, A Vindication of Natural Society:, in Edmund Burke, The Works of the Hon. Edmund Burke, (London: John Nommo, 1887), vol. 1, p. 46.

5 Kant was always unequivocal about his debt to Rousseau. In his Nachlass ('Unpublished Writings') - Kant writes 'I am an investigator by inclination. I feel a great thirst for knowledge and an impatient eagerness to advance, also satisfaction at each progressive step. There was a time when I thought that all this could constitute the honour of humanity, and I despised the mob, which knows nothing. Rousseau put me straight. This dazzling excellence vanishes. I learn to honour men, and would consider myself much less useful than common labours if I did not believe that this consideration could give all the others a value, to establish the rights of humanity.' Immanuel Kant, Fragmente aus dem Nachlässe, in Kants Sämtliche Werke (Leipzig: Leopold Voss, 1868), vol. VIII, p. 624.

6 Fernon has noted: 'communities can no longer be based simply on arrangements in which individuals maximise their desires within a bare legal framework of seeming non-interference, [hence for Rousseau] the cultivation and education of sentiments attain overarching importance' N. Fernon, Domesticating Passions. Rousseau, Women and Nation (London: Wesleyan University Press, 1997), pp. 5-6.

7 Of course. Rousseau had plenty to say about women - though not always things which have endeared him to latterday feminists. As Nancy Hirschman has written, 'since feminist political theory began as a subfield ... that famous sexist Jean-Jacques Rousseau has been the political theorist that feminists love to hate'. Nancy Hirschman, 'Rousseau's Republican Romance', review article, Political Theory, vol. 30, no. 1 (2000), 164. A new approach by feminists is contained in Elizabeth Rose Wingrove's Rousseau's Republican Romance. Wingrove reads Rousseau metaphorically, arguing that Rousseau's 'republicanism consists in proper performance of masculinity and femininity'. She goes on to show - so it is argued - that 'republican identity is constructed through sexual identities, and sexual identities through political forms'. See Elisabeth Rose Wingrove, Rousseau's Republican Romance (Princeton: Princeton University Press, 2000), p. 6; p. 167. Nicole Fermon also has seen gender as the main theme in his philosophy: 'women, both real 
and metaphorical, are at the centre of [Rousseau's] project to reform politics, which for Rousseau means all human relations. Women, for Rousseau ... primarily means the mother - the place of repair and consolation, of feeding, of reassurance, that which resist separation(s).' Nicole Fermon, Domesticating Passions. Rousseau, Woman, and Nation (Hanover and London: Wesleyan University Press, 1997), p. 4. For a more thorough treatment of the subject the reader may wish to consult: Paul Hoffman, 'Le mythe de la femme dans la pensée de Jean-Jacques Rousseau', in La femme dans la pensée des Lumières (Paris: Ophrys, 1977), pp. 359-446; Joel Schwartz, The sexual politics of JeanJacques Rousseau (Chicago: University of Chicago Press, 1984); Mary Seidman Trouille, Sexual politics in the Enlightenment: women writers read Rousseau (Albany: SUNY Press, 1997). 